\title{
The Effects of Ghrelin on Renal Complications in Newborn Diabetic Rats
}

\author{
Ayse Karatug Kacar ${ }^{1}$ (D), Ozlem Sacan ${ }^{2}$ (D) Neslihan Ozicli ${ }^{3}$ (D), Sehnaz Bolkent ${ }^{1}$ (D), \\ Refiye Yanardag ${ }^{2}$ D, Sema Bolkent ${ }^{3}$ \\ IIstanbul University, Faculty of Science, Department of Biology, Istanbul, Turkey \\ ${ }^{2}$ Istanbul University-Cerrahpasa, Faculty of Engineering, Department of Chemistry, Istanbul, Turkey \\ ${ }^{3}$ Istanbul University-Cerrahpasa, Cerrahpasa Faculty of Medicine, Department of Medical Biology, Istanbul, Turkey
}

ORCID IDs of the authors: A.K.K. 0000-0001-6032-470X; O.S. 0000-0001-6503-4613; N.O. 0000-0001-9991-3421; S.B. 0000-0002-1112-5162; R.Y. 0000-0003-4185-4363; S.B. 0000-0001-8463-5561

Please cite this article as: Karatug Kacar A, Sacan O, Ozicli N, Bolkent S, Yanardag R, Bolkent S. The Effects of Ghrelin on Renal Complications in Newborn Diabetic Rats. Eur J Biol 2020; 79(1): 1-6. DOI: 10.26650/EurJBiol.2020.0043

\begin{abstract}
Objective: Ghrelin is an orexigenic hormone mainly released from the stomachs of rats and takes a significant part in the development of newborn rats. Ghrelin has been shown to possess antioxidant, anti-apoptotic, and anti-inflammatory properties. In this study, we aimed to examine microscopical and biochemical parameters in the kidney of newborn nontreated diabetic and ghrelin-treated diabetic rats.
\end{abstract}

Materials and Methods: Wistar-type newborn rats were divided into four groups. First group: control rats given physiological saline for four weeks; second group: control animals given ghrelin from the third day to the fourth week; third group: diabetic rats given streptozotocin (STZ) on the second day after birth as a single dose; fourth group: diabetic rats given ghrelin from the third day to the fourth week.

Results: There was no microscopic difference between the kidney tissues of non-treated diabetic and ghrelin-treated diabetic rats. Lipid peroxidation levels decreased, while superoxide dismutase, catalase activities, and glutathione levels increased in the diabetic group given ghrelin. Serum urea, uric acid, creatinine levels, myeloperoxidase, and xanthine oxidase activities decreased in diabetic rats treated with ghrelin.

Conclusion: It can be said that the ghrelin given exogenously has a protective effect in some degree on renal complications in newborn diabetic rats.

Keywords: Diabetes, ghrelin, kidney

\section{INTRODUCTION}

The pancreas has four main types of endocrine cells. The first one of them is alpha cells, which synthesize glucagon, the second one is beta cells, which synthesize insulin, the third one is delta cells, which synthesize somatostatin, the fourth one is pancreatic polypeptide (PP) cells, which synthesize pancreatic polypeptide (1-3), and the fifth type is ghrelin cells, which synthesize ghrelin in mammalian pancreatic islet cells $(4,5)$. Ghrelin cells are the most important source of ghrelin in the fetal peri- od (6). Their number increases during this period, and these cells are located around pancreatic islands $(4,5)$. It has been shown that when the number of beta cells decreases, the number of ghrelin cells increases in experimental mouse models (5). Ghrelin controls glucose metabolism (7). Ghrelin levels decrease in type 2 diabetes individuals and healthy offspring of them (8-10). There is a relationship between ghrelin and insulin levels. The authors demonstrated that insulin plays an important role in inhibition of nutrition-related ghrelin as a modu- 
lator of plasma ghrelin $(11,12)$. Furthermore, the hyperglycemic and lowering effect also occurred when ghrelin is given to a healthy human. These findings reveal effects of ghrelin on insulin secretion and glucose metabolism $(13,14)$.

Diabetes mellitus is a chronic metabolic disease. Prolonged hyperglycemia causes damage to some tissues, such as kidney tissue, and an increase in oxidative stress. This situation induces renal damage. Therefore, kidney damage is associated with increased oxidative stress (15). Renal failures are the cause of diabetic nephropathy. One of the mortalities caused in patients who have insulin-dependent and non-insulin-dependent diabetes is renal disease (16). Diabetic nephropathy is a major problem in diabetic patients (17). Reactive oxygen species (ROS) has an important role in diabetic pathogenesis (18). Antioxidants protect cells and tissues from oxidative damage (19). The kidney damage caused by oxidative stress is reduced by increased antioxidant levels. Ghrelin may be an important antioxidant agent with increasing antioxidant enzyme activities $(20,21)$. Increased ROS levels and decreased antioxidant levels are observed in diabetes (22). Then, free radicals come into play, and this situation occurs with nonenzymatic glycation of proteins, oxidation of glucose, increase of lipid peroxidation (LPO), and the development of insulin resistance (23). Oxidative stress emerges from an imbalance between the formed radicals and the level of antioxidants. It has been shown in many studies that complications that occur in diabetes cause the development of oxidative stress $(18,24,25)$. Ghrelin has an antioxidant effect and is a strong lipolytic hormone (26). Fujimura et al. demonstrated that ghrelin has a significant role in the decrease of ROS levels in angiotensin II -induced renal damage in mice (27).

In the present study, it was purposed to reveal the anti-proliferative and antioxidants effects of ghrelin microscopically and biochemically in the kidney of newborn normal and STZ-induced diabetic rats following exogenous administration of ghrelin.

\section{MATERIAL AND METHODS}

\section{Animals}

The Local Ethics Committee on Animal Research of Istanbul University approved for all the experimental procedures. In this study, newborn Wistar albino female and male rats were divided into four groups ( $n=5$ per group, totally 20 rats in histological and immunohistochemical assays; $n=13$ for control and ghrelin control groups, $\mathrm{n}=9$ for diabetic and diabetic group given ghrelin, totally 44 rats in biochemical assays). In the first group, which was the control group, physiological saline was given intraperitoneally for four weeks. Ghrelin (AnaSpec, Fremont, CA, USA, 24160) was given subcutaneously as 100 mg/kg/ day from the third day to the fourth week to the second group rats. Rats in the third group, which was the diabetic group, were treated with a single dose of $100 \mathrm{mg} / \mathrm{kg}$ streptozotocin (STZ) on the second day after birth to induce newborn diabetes, intraperitoneally. Ghrelin after STZ injection was given to the rats in the last group. At the end of the experiment, the rats were sacrificed. Their blood samples were taken for biochemical analysis, and kidney tissues were taken for examining microscopical and biochemical parameters.

\section{Histological and Immunohistochemical Assays}

Kidney tissues fixed in Bouin's solution for 24 hours at room temperature were used. After the series of ethanol and xylene for dehydration and cleaning, the kidney tissues were embedded in paraffin. The embedded kidney tissues were cut as a 5 $\mu \mathrm{m}$ section for a histological assay and a $4 \mu \mathrm{m}$ section for an immunohistochemical assay. The kidney tissues were stained with a Periodic Acid Schiff reagent for microscopy analysis. The poly-L-lysine was used to coat microscope slides. The sections were placed on these slides for the immunohistochemical assay. Caspase-3 and proliferating cell nuclear antigen (PCNA) were investigated for immunohistochemical assay. The paraffin was removed by keeping the sections in toluene. After this stage, the sections were incubated with hydrogen peroxide (3\%) to block the endogenous peroxidase activity. The Histostain Plus Broad Spectrum Kit (Zymed, 85-9743, South San Francisco, CA), PCNA antibody (Ab-1 MS-106-P, Neomarkers, Fremond, CA, dilution 1:50, 30 minutes at room temperature), and caspase-3 (Millipore AB3623, Bedford, MA, USA; dilution 1:50, overnight at $+4^{\circ} \mathrm{C}$ ) were utilized for immunohistochemical labeling by employing the streptavidin-biotin-peroxidase technique. The 3-amino-9-ethyl carbazole was used to detect of immunoreactivity. Mayer's hematoxylin was used for counterstain of the sections and mounted using glycerol vinyl alcohol mounting medium.

Histological and immunohistochemical assays were conducted by using an X40 objective and X10 ocular system of the Olympus CX-45 microscope as Microscopic analysis. The results were explained by the histological score with a grade from 0 to 3 as negative (0), weak (1), moderate (2), and strong (3). PCNA immunopositive cells were counted for each slide at a minimum of ten random fields.

\section{Biochemical Assays}

In the previous study, blood glucose levels were measured, and Turk et al. decided that the rats were diabetic (28). Creatinine, uric acid, and serum urea levels were investigated by the methods of Jaffe reaction (29), Caraway (30), and acetylmonoxime (31), respectively. Cold $0.9 \% \mathrm{NaCl}$ and glass equipment were used for homogenization of kidney tissues. $10 \%(w / v)$ homogenate was obtained. It was centrifuged. Clear supernatants were utilized for protein, glutathione (GSH), and LPO levels and antioxidant enzyme analysis. GSH levels were determined in accordance with the Beutler method using Ellman's reagent (32). LPO levels were investigated by Ledwozyw's method in kidney homogenates (33). Catalase (CAT) activity was determined in accordance with Aebi (34), superoxide dismutase (SOD) activity in accordance with Mylroie's method (35), myeloperoxidase (MPO) activity in accordance with Wei and Frenkel (36), and xanthine oxidase (XO) activity in accordance with Corte and Stirpe with a number of modifications (37). The protein level was determined by employing the method of Lowry in the supernatants. The bovine serum albumin was used as standard for this method (38). 


\section{Statistical Analysis}

The Mann-Whitney $U$ tests and the two-way ANOVA using GraphPad Prism version 4.0 computer package were used for analysis of the histological and immunohistochemical data. The unpaired Student's $t$-test and one-way ANOVA using the NCSS statistical computer package were used for the biochemical results. The results were presented as mean \pm SE for histological and immunohistochemical assays; as mean \pm SD for biochemical assays. $P$ values less than 0.05 were considered significant.

\section{RESULTS}

\section{Histological and Immunohistochemical Assays}

Degenerative changes such as expansion in the capsular spaces of glomeruli, ruptures at the brush border in apical, desquamated nuclei and cytoplasmic debris in the lumen of proximal tubules, necrotic areas, moderate cytoplasmic vacuolar degeneration, and hyperemia in the kidney tissue of rats given STZ were determined. These changes were not changed in the kidney tissue of the diabetic animals given ghrelin (Figure 1).
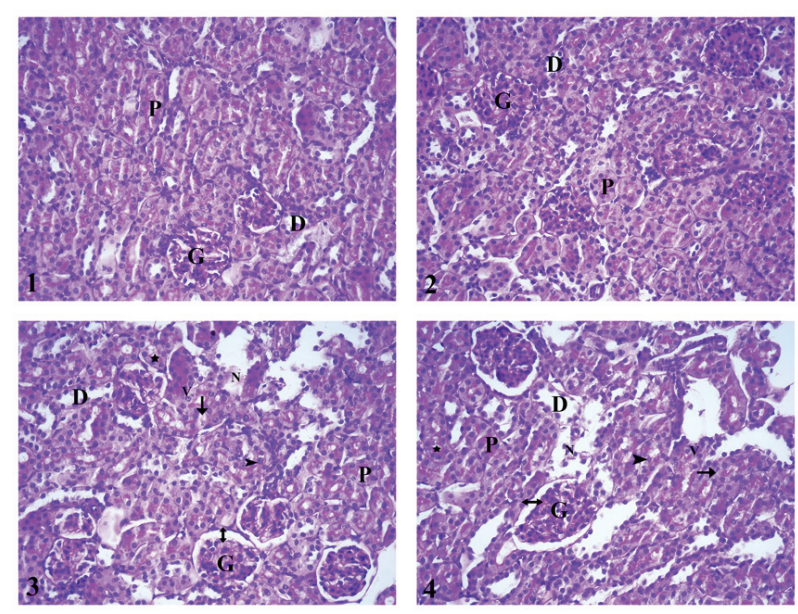

Figure 1. A normal histological appearance was observed in the kidney tissue of the control (1), control group given ghrelin (2), STZ group (3), diabetic group given ghrelin (4). G: Glomeruli, P: Proximal tubules, D: Distal tubules, N: Necrotic area, V: Vacuolar degeneration, $\rightarrow$ : Ruptures at the brush border in apical, *: Cytoplasmic debris and $>$ : Desquamated nuclei in the lumen of proximal tubules, $\leftrightarrow$ : Expansion in capsular spaces of glomeruli. Periodic Acid Schiff (PAS) staining technique. 400x magnification
PCNA immune ${ }^{+}$cell number as cell proliferation increased in the diabetic group given STZ compared to both the control groups. In the diabetic group given ghrelin, cell proliferation decreased compared to the control group given ghrelin, while it decreased in comparison with the diabetic group. PCNA immune ${ }^{+}$cell number (Figures 2A and 2B) was observed. Caspase-3 immune ${ }^{+}$ cell number did not exhibit a difference between the four groups statistically (Data not shown).

\section{Biochemical Assays}

The serum uric acid and urea levels in the diabetic group were determined to have increased significantly in comparison with the control group $(p<0.001 ; p<0.05)$. Ghrelin caused a significant decrease in creatinine, uric acid, and urea levels in the diabetic group $(p<0.0001 ; p<0.001 ; p<0.05)$ (Table 1$)$.

A

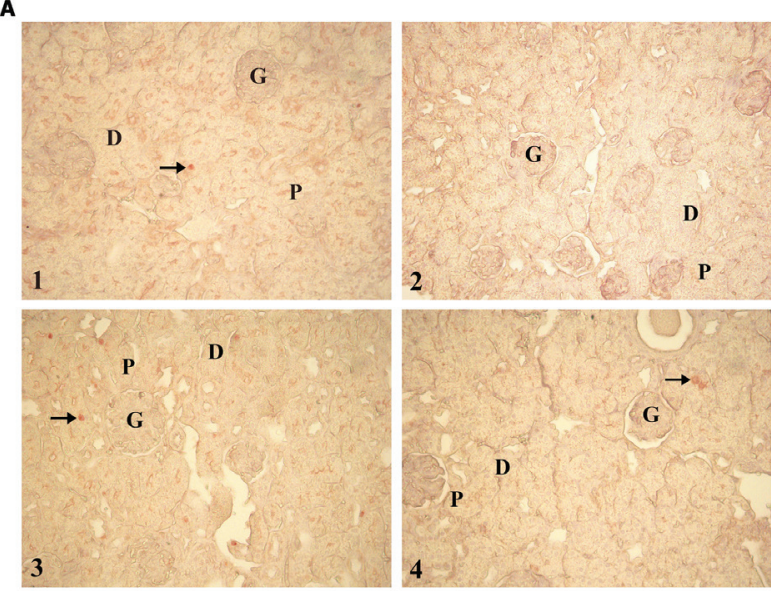

B

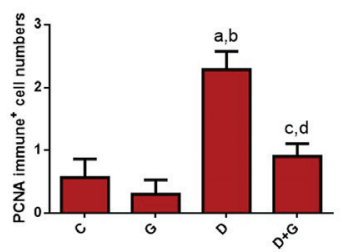

Figure 2. A) PCNA immune ${ }^{+}$cells $(\rightarrow)$ are observed with immunohistochemistry in kidney tissue of the control group (1), control group given ghrelin (2), STZ group (3), diabetic group given ghrelin (4). G: Glomeruli, P: Proximal tubules, D: Distal tubules. B) PCNA immune ${ }^{+}$cell number for all groups. ${ }^{a} p<0.05$ versus control group, ${ }^{b} p<0.01$ versus ghrelin group, $c p<0.05$ versus ghrelin group, ${ }^{d} p<0.01$ versus diabetic group. $400 x$ magnification

Table 1. Serum urea, creatinine and uric acid levels of all groups

\begin{tabular}{|c|c|c|c|}
\hline Group & Urea (mg/dL)* & Creatinine $(\mathrm{mg} / \mathrm{dL}) *$ & Uric Acid (mg/L)* \\
\hline Control & $59.84 \pm 7.48$ & $1.32 \pm 0.15$ & $4.23 \pm 0.22$ \\
\hline Control+Ghrelin & $76.19 \pm 26.14$ & $0.65 \pm 0.23^{c}$ & $3.39 \pm 0.67^{\mathrm{a}}$ \\
\hline Diabetic & $106.41 \pm 20.41^{a}$ & $1.42 \pm 0.02^{d}$ & $5.14 \pm 0.39^{f}$ \\
\hline Diabetic+Ghrelin & $72.79 \pm 5.84^{b}$ & $0.51 \pm 0.03^{e}$ & $3.20 \pm 0.67^{9}$ \\
\hline$P_{\text {ANOVA }}$ & 0.041 & 0.0001 & 0.0001 \\
\hline
\end{tabular}


Table 2. Kidney glutathione (GSH) and lipid peroxidation (LPO) levels of all groups

\begin{tabular}{|c|c|c|}
\hline Group & $\begin{array}{l}\text { GSH (nmol GSH/mg } \\
\text { protein)* }\end{array}$ & $\begin{array}{l}\text { LPO (nmol MDA/ } \\
\text { mg protein)* }\end{array}$ \\
\hline Control & $10.46 \pm 3.56$ & $0.39 \pm 0.03$ \\
\hline Control+ Ghrelin & $9.64 \pm 2.63$ & $0.41 \pm 0.04$ \\
\hline Diabetic & $2.73 \pm 1.15^{\mathrm{a}}$ & $0.65 \pm 0.05^{c}$ \\
\hline Diabetic+ Ghrelin & $11.31 \pm 2.21^{b}$ & $0.37 \pm 0.07^{d}$ \\
\hline$P_{\text {ANOVA }}$ & 0.0001 & 0.0001 \\
\hline
\end{tabular}

A significant reduction in GSH levels was determined in the diabetic group in comparison with the control groups $(p<0.0001)$. Ghrelin administered to the diabetic rats induced a significant increase in GSH levels in the kidney $(p<0.0001)$. LPO levels was increase significantly in the diabetic rats compared to the control groups $(p<0.001)$. There was a decrease in LPO levels in the kidney with given ghrelin to STZ-diabetic rats $(p<0.001)$ (Table 2$)$.

A significant reduction in kidney CAT and SOD activities were determined in the diabetic group in comparison with the control groups $(p<0.0001)$. However, MPO and XO activities significantly increased in the diabetic group compared to the control group ( $<<0.001 ; p<0.05$ ) (Table 3 ). The exogenously administered ghrelin induced an increase in kidney CAT and SOD activities ( $p<0.001 ; p<0.005)$, and a decrease in kidney MPO and XO activities in the diabetic rats $(p<0.05 ; p<0.0001)$ (Table 3 ). betic rats (40). Renal damage caused by ischemia/reperfusion or cisplatin showed that ghrelin administration reduced apoptosis $(41,42)$. In the present study, some degenerative changes in the STZ treated kidney tissue of newborn rats were determined. Ghrelin did not reverse these changes in diabetic animals. Ghrelin did not affect the renal injury of experimental diabetic rats microscopically. However, PCNA immune ${ }^{+}$cell number decreased with the administration of ghrelin in diabetic rats. Proximal tubule epithelial cells start to proliferate to prevent acute injury $(43,44)$. Proliferation increases in the proximal tubule after injury. Therefore, the occurred cell number decrease by cell death is compensated (45). Danilewicz and Wagrowska-Danilewicz suggest that cell proliferation was inhibited by ghrelin in control kidney tissues and non-proliferative glomerulopathies. The lack or low level of this protein in proliferative glomerulopathies was observed (46). It was thought that when the cells were damaged, it increased the number of cells to prevent damage. Therefore, PCNA immune ${ }^{+}$cell number increased in the diabetic group. It decreased because of reduced damage with the administration of ghrelin.

Necrotic areas in the kidney tissue of the experimental group were determined by histochemical staining, and it was desired to investigate caspase-3 activity to determine apoptosis, a form of cell death. There were no changes in caspase-3 between the four groups. We thought that cell death might occur in the diabetic group. However, apoptotic cell death did not occur with the administration of STZ, statistically.

Table 3. Kidney catalase (CAT), superoxide dismutase (SOD), myeloperoxidase (MPO) and xanthine oxidase (XO) activities of all groups

\begin{tabular}{lllll}
\hline Group & CAT (U/mg protein)* & SOD (U/g protein)* & MPO (U/g tissue)* & XO (U/g protein) \\
\hline Control & $291.45 \pm 41.44$ & $15.05 \pm 4.57$ & $41.57 \pm 5.87$ & $1.89 \pm 0.67$ \\
Control+Ghrelin & $218.32 \pm 86.91^{\mathrm{a}}$ & $11.60 \pm 4.84$ & $44.07 \pm 11.91$ & $1.31 \pm 0.82$ \\
\hline Diabetic & $211.83 \pm 36.69^{\mathrm{b}}$ & $7.47 \pm 0.88^{\mathrm{b}}$ & $83.10 \pm 14.84^{\mathrm{e}}$ & $2.60 \pm 0.28^{\mathrm{a}}$ \\
Diabetic+Ghrelin & $269.01 \pm 8.82^{\mathrm{c}}$ & $9.66 \pm 1.41^{\mathrm{d}}$ & $38.03 \pm 14.63^{\mathrm{f}}$ & $1.73 \pm 0.19^{\mathrm{g}}$ \\
\hline $\mathrm{P}_{\text {ANOVA }}$ & 0.003 & 0.001 & 0.001 & 0.001 \\
\hline
\end{tabular}

*Mean $\pm S D$; a $p<0.05$ versus control group, ${ }^{b} p<0.0001$ versus control group, $c p<0.001$ versus diabetic group, ${ }^{d} p<0.005$ versus diabetic group, ${ }^{e} p<0.001$ versus control group, ${ }^{f} p<0.05$ versus diabetic group and ${ }^{g} p<0.0001$ versus diabetic group.

\section{DISCUSSION}

The blood glucose levels decreased in diabetic rats given ghrelin compared to non-treated diabetic rats (28). Ghrelin administration inhibits the diabetic effects as a result of reducing the blood glucose levels in newborn diabetic rats. Brouwers et al. showed that kidney damage occurred as a result of administering $250 \mathrm{mg} / \mathrm{kg}$ STZ doze to mice (39). They have observed disruption of the brush border, the loss of nucleus in proximal tubule cells, dilatation of non-proximal tubules, and moderate acute tubular injury. Koyuturk et al. found that ghrelin reduced cell proliferation and caspase 8 activity, while caspase- 3 activity did not change in the liver tissue of ghrelin-administrated dia-
Creatinine levels decreased with the administration of ghrelin in renal damage caused by cisplatin (42). In another study, creatinine levels were shown to be higher compared to the control group in diabetic nephropathy $(47,48)$. Van Ginhoven et al. have shown that urea levels increased after reperfusion (49). However, there were no changes between both the control group and the group given ghrelin. Furthermore, uric acid, urea, and creatinine levels increased in an experimental model of diabetic nephropathy compared to the control group (50). In our study, uric acid, creatinine, and serum urea levels reduced in the diabetic group given ghrelin. It can be said that ghrelin takes a significant part in the prevention of renal damage. 
Ghrelin increases antioxidant activity. Therefore, it has antioxidant properties in the rat kidney tissue (51). The authors indicated that SOD and GSH levels reduced in the kidney tissue in the diabetic group compared to the control group (52). In another similar study, CAT, SOD activities and GSH levels reduced, while malondialdehyde levels increased in diabetic nephropathy in comparison with the control group (50). Sudhakara et al., have shown that LPO and XO levels increased in the kidney tissue of diabetic rats (53). Sacan et al., has shown that LPO, CAT, SOD, MPO, and XO significantly increased, while GSH levels reduced in lung tissues in diabetic rats in comparison with the control group (54). In our study, kidney GSH level, SOD, and CAT activities significantly increased, while XO and MPO activities and LPO level significantly reduced in the diabetic group given ghrelin. Ghrelin reversed biochemical changes in diabetic rats.

\section{CONCLUSION}

The biochemical results showed that ghrelin provides recovery of complications in kidney tissue in newborn diabetic rats. Ghrelin treatment partially reversed the renal injury of experimental diabetic rats because of the antioxidant properties of ghrelin.

\section{Peer-review: Externally peer-reviewed.}

Author Contributions: Conception/Design of study: S.B., N.O.; Data Acquisition: A.K.K., O.S., R.Y.; Data Analysis/Interpretation: A.K.K., O.S., R.Y.; Drafting Manuscript: A.K.K.; Critical Revision of Manuscript: A.K.K., O.S., S.B., R.Y., S.B.; Final Approval and Accountability: A.K.K., O.S., S.B., R.Y., S.B.; Technical or Material Support: S.B., O.S., R.Y., S.B.; Supervision: S.B.

Conflict of Interest: The authors declare that they have no conflicts of interest to disclose.

Financial Disclosure: This work was supported by Scientific Research Project Coordination Unit of Istanbul University. Project No. BYP-36942.

\section{REFERENCES}

1. Edlund H. Developmental biology of the pancreas. Diabetes 2001; 50(Suppl 1): S5-S9.

2. Brissova M, Fowler MJ, Nicholson WE, Chu A, Hirshberg B, Harlan $\mathrm{DM}$, et al. Assessment of human pancreatic islet architecture and composition by laser scanning confocal microscopy. J Histochem Cytochem 2005; 53: 1087-97.

3. Cabrera O, Berman DM, Kenyon NS, Ricordi C, Berggren PO, Caicedo $A$. The unique cytoarchitecture of human pancreatic islets has implications for islet cell function. Proc Natl Acad Sci USA 2006; 103: 2334-9.

4. Wierup N, Svensson H, Mulder H, Sundler F. The ghrelin cell: a novel developmentally regulated islet cell in the human pancreas. Regul Pept 2002; 107: 63-9.

5. Prado $C L$, Pugh-Bernard AE, Elghazi L, Sosa-Pineda B, Sussel L. Ghrelin cells replace insulin-producing beta cells in two mouse models of pancreas development. Proc Natl Acad Sci USA 2004; 101: 2924-9.
6. Chanoine JP, Wong AC. Ghrelin gene expression is markedly higher in foetal pancreas compared with foetal stomach: effect of maternal fasting. Endocrinology 2004; 145: 3813-20.

7. O. Ukkola, Ghrelin and metabolic disorders. Curr Protein Pept Sc 2009; 10-1: 2-7.

8. Ostergard T, Hansen TK, Nyholm B, Gravholt CH, Djurhuus CB, Hosoda $\mathrm{H}$, et al. Circulating ghrelin concentrations are reduced in healthy offspring of type 2 diabetic subjects, and are increased in women independent of a family history of type 2 diabetes. Diabetologia 2003; 46-1: 134-6.

9. Poykko SM, Kellokoski E, Horkkoe S, Kauma H, Kesäniemi YA, Ukkola O. Low plasma ghrelin is associated with insulin resistance, hypertension, and the prevalence of type 2 diabetes. Diabetes 2003;52-10: 2546-53.

10. Barazzoni R, Zanetti M, Ferreira C, Vinci P, Pirulli A, Mucci M, et al. Relationships between desacylated and acylated ghrelin and insulin sensitivity in the metabolic syndrome. J Clin Endocrinol Metab 2007; 92: 3935-40.

11. McCowen KC, Maykel JA, Bistrian BR, Ling PR. Circulating ghrelin concentrations are lowered by intravenous glucose or hyperinsulinemic euglycemic conditions in rodents. J Endocrinol 2002; 175: R7-R11.

12. Saad MF, Bernaba B, Hwu CM, Jinagouda S, Fahmi S, Kogosov E, et al. Insulin regulates plasma ghrelin concentration. J Clin Endocrinol Metab 2002; 87: 3997-4000.

13. Broglio F, Arvat E, Benso A, Gottero C, Muccioli G, Papotti M, et al. Ghrelin, a natural GH secretagogue produced by the stomach, induces hyperglycemia and reduces insulin secretion in humans. J Clin Endocrinol Metab 2001; 86: 5083-6.

14. Broglio F, Gottero C, Prodam F, Gauna C, Muccioli G, Papotti M, et al. Non-acylated ghrelin counteracts the metabolic but not the neuroendocrine response to acylated ghrelin in humans. J Clin Endocrinol Metab 2004; 89: 3062-5.

15. Nasri $\mathrm{H}$, eian-Kopaei MR. Protective effects of herbal antioxidants on diabetic kidney disease. J Res Med Sci 2014; 82-3.

16. Cooper ME. Pathogenesis, prevention, and treatment of diabetic nephropathy. Lancet 1998; 352: 213-9.

17. Winegrad Al. Banting lecture 1986. Does a common mechanism induce the diverse complications of diabetes? Diabetes 1987; 36(3): 396-406.

18. Baynes, J.W. Role of oxidative stress in development of complications in diabetes. Diabetes 1991; 40: 405-12.

19. Freeman BA, Crapo JD. Biology of disease: free radicals and tissue injury. Lab Invest 1982; 47(5): 412-26.

20. Obay BD, Tasdemir E, Tumer C, Bilgin H, Atmaca M. Dose dependent effects of ghrelin on pentylenetetrazole-induced oxidative stress in a rat seizure model. Peptides 2008; 29: 448-55.

21. Zwirska-Korczala K, Adamczyk-Sowa M, Sowa P, Pilc K, Suchanek R, Pierzchala K, et al. Role of leptin, ghrelin, angiotensin $\Pi$ and orexins in 3 T3 L1 preadipocyte cells proliferation and oxidative metabolism. J Physiol Pharmacol 2007; 58: 53-64.

22. Wiernsperger NF. Oxidative stress as a therapeutic target in diabetes: revisiting the controversy. Diabetes Metab 2003; 29: 579-85.

23. Maritim AC, Sanders RA, Watkins III JB. Diabetes, oxidative stress, and antioxidants:a review. J Biochem Mol Toxicol 2003; 17: 24-38.

24. Monnier L, Colette C, Mas E, Michel F, Cristol JP, Boegner C, et al. Regulation of oxidative stress by glycaemic control: evidence for an independent inhibitory effect of insulin therapy. Diabetologia 2009; 53: 562-71.

25. Aslam F, lqbal S, Nasir M, Anjum AA. White sesame seed oil mitigates blood glucose level, reduces oxidative stress, and improves biomarkers of hepatic and renal function in participants with type 2 diabetes mellitus. J Am Coll Nutr 2018; 27: 1-12. 
26. Korbonits M, Goldstone AP, Gueorguiev M, Grossman AB. Ghrelin a hormone with multiple functions. Front Neuroendocrinol 2004; 25(1): 27-68.

27. Fujimura K, Wakino S, Minakuchi H, Hasegawa K, Hosoya K, Komatsu $\mathrm{M}$ et al. Ghrelin protects against renal damages induced by angiotensin-II via an antioxidative stress mechanism in mice. PLoS One 2014; 9(4): e94373.

28. Turk N, Dagistanli FK, Sacan O, Yanardag R, Bolkent S. Obestatin and insulin in pancreas of newborn diabetic rats treated with exogenous ghrelin. Acta Histochem 2012; 114(4): 349-57.

29. Bonsnes RW, Taussky HH. On the colorimetric determination of creatinine by the Jaffe reaction. J Biol Chem 1945; 158: 581-91.

30. Caraway WT. Determination of uric acid in serum by a carbonate method. Am J Clin Pathol 1955; 25(7): 840-5.

31. Barker SB. The direct colorimetric determination of urea in blood and urine. J Biol Chem 1944; 152: 453-63.

32. Beutler E. Glutathione in red cell metabolism. In: A Manual of Biochemical Methods. New York: Grune and Stratton 1975; pp. 112-4.

33. Ledwozyw A, Michalak J, Stepien A, Kadziołka A. The relationship between plasma triglycerides, cholesterol, total lipids and lipid peroxidation products during human atherosclerosis. Clin Chim Acta 1986; 155: 275-83.

34. Aebi H. Catalase in vitro. Methods Enzymol 1984; 105: 121-6.

35. Mylorie AA, Collins H, Umbles C, Kyle J. Erythrocyte superoxide dismutase activity and other parameters of copper status in rats ingesting lead acetate. Toxicol Appl Pharmacol 1986; 82: 512-20.

36. Wei $\mathrm{H}$, Frenkel $\mathrm{K}$. In vivo formation of oxidized DNA bases in tumor promoter-treated mouse skin. Cancer Res 1991; 51(16): 4443-9.

37. Corte ED, Stirpe F. Regulation of xanthine oxidase in rat liver: Modifications of the enzyme activity of rat liver supernatant on storage at 20 degrees. Biochem J 1968; 108: 349-51.

38. Lowry OH, Rosebrough NJ, Farr AL, Randall RJ. Protein measurement with the Folin phenol reagent. J Biol Chem 1951; 193: 265-75.

39. Brouwers B, Pruniau VP, Cauwelier EJ, Schuit F, Lerut E, Ectors N, et al. Phlorizin pretreatment reduces acute renal toxicity in a mouse model for diabetic nephropathy. J Biol Chem 2013; 288(38): 27200-7.

40. Koyuturk M, Sacan O, Karabulut S, Turk N, Bolkent S, Yanardag R, et al. The role of ghrelin on apoptosis, cell proliferation and oxidant-antioxidant system in the liver of neonatal diabetic rats. Cell Biol Int 2015; 39(7): 834-41.

41. Takeda R, Nishimatsu H, Suzuki E, Satonaka H, Nagata D, Oba S, et al. Ghrelin improves renal function in mice with ischemic acute renal failure. J Am Soc Nephrol 2006; 17(1): 113-21.

42. Nojiri T, Hosoda H, Kimura T, Tokudome T, Miura K, Takabatake H, et al. Protective effects of ghrelin on cisplatin-induced nephrotoxicity in mice. Peptides 2016; 82: 85-91.
43. Cuppage FE, Neagoy DR, Tate A. Repair of the nephron following temporary occlusion of the renal pedicle. Lab Invest 1967; 17: 66074.

44. Witzgall R, Brown D, Schwarz C, Bonventre JV. Localization of proliferating cell nuclear antigen, vimentin, c-Fos, and clusterin in the postischemic kidney. Evidence for a heterogenous genetic response among nephron segments, and a large pool of mitotically active and dedifferentiated cells. J Clin Invest 1994; 93: 2175-88.

45. Guo JK, Cantley LG. Cellular maintenance and repair of the kidney. Annu Rev Physiol 2010; 72: 357-76.

46. Danilewicz M, Wagrowska-Danilewicz M. Renal immunoexpression of ghrelin is attenuated in human proliferative glomerulopathies. Nefrologia 2010; 30(6): 633-8.

47. Li Y, Liu J, Liao G, Zhang J, Chen Y, Li L, et al. Early intervention with mesenchymal stem cells prevents nephropathy in diabetic rats by ameliorating the inflammatory microenvironment. Int J Mol Med 2018; 41(5): 2629-39.

48. Wang D, Zhang G, Chen X, Wei T, Liu C, Chen C, et al. Sitagliptin ameliorates diabetic nephropathy by blocking TGF- $\beta 1 /$ Smad signaling pathway. Int J Mol Med 2018; 41(5): 2784-92.

49. van Ginhoven TM, Huisman TM, van den Berg JW, ljzermans JN, Delhanty PJ, de Bruin RW. Preoperative fasting induced protection against renal ischemia/reperfusion injury is independent of ghrelin in mice. Nutr Res 2010; 30(12): 865-9.

50. Yaribeygi $H$, Mohammadi MT, Rezaee R, Sahebkar A. Fenofibrate improves renal function by amelioration of NOX-4, IL-18, and p53 expression in an experimental model of diabetic nephropathy. J Cell Biochem 2018; 119(9): 7458-69.

51. Neamati S, Alirezaei M, Kheradmand A. Ghrelin Acts as an Antioxidant Agent in the Rat Kidney. Int J Pept Res Ther 2011; 17-3: 23945.

52. Elsherbiny NM, Zaitone SA, Mohammad HMF, El-Sherbiny M. Renoprotective effect of nifuroxazide in diabetes-induced nephropathy: impact on NFjB, oxidative stress, and apoptosis. Toxicol Mech Method 2018; 28-6: 467-473.

53. Sudhakara G, Ramesh B, Mallaiah P. Sreenivasulu N, Saralakumari D. Protective effect of ethanolic extract of Commiphora mukul gum resin against oxidative stress in the brain of streptozotocin induced diabetic Wistar male rats. Excli J 2012; 11: 576-92.

54. Sacan O, Turkyilmaz IB, Bayrak BB, Mutlu O, Akev N, Yanardag R. Zinc supplementation ameliorates glycoprotein components and oxidative stress changes in the lung of streptozotocin diabetic rats. Biometals 2016; 29(2): 239-48. 